\title{
Kanker serviks dan gen Fas-promoter-670
}

\author{
MLE Parwanto \\ Departemen Biologi, Fakultas Kedokteran Universitas Trisakti, Indonesia \\ Email: edyparwanto@trisakti.ac.id; edy.parwanto@gmail.com
}

Kanker serviks merupakan keganasan pada serviks. Jenis kanker tersebut terjadi pada perempuan dan masih menjadi masalah di Indonesia. Indonesia merupakan negara urutan ke 4 di Asia Tenggara dengan insiden kanker serviks terbesar setelah Kamboja, Myanmar dan Thailand. Berdasar data statistik tahun 2012, tingkat insidensi (incidence rate) kanker serviks di Indonesia 17 per 100.000 perempuan per tahun. (1)

Telah terbukti bahwa penyebab primer terjadinya kanker serviks yaitu virus papilloma atau yang lebih dikenal dengan istilah "human papillomavirus ( $H P V)$ ”. Terdapat beberapa jenis serotype HPV, tetapi tidak semua jenis serotype bersifat progesif menjadikan kanker serviks. Salah satu serotype yang bersifat progesif menjadikan kanker serviks yaitu HPV serotype 16. HPV serotype 16 mampu mengubah sel epitel squamosa serviks (cervical-squamous-epithelial cells $=C S E C$ ) normal menjadi lesi intraepitelial squamosa tingkat rendah (low-grade squamous intraepithelial lesion $=$ LSIL) atau neoplasia intraepitel serviks (cervical intraepithelial neoplasia $=$ CIN) 1. Selanjutnya, LSIL atau CIN 1 berkembang menjadi lesi intraepitelial squamosa tingkat tinggi (high-grade squamous intraepithelial lesion=HSIL) atau CIN 2, dan akhirnya menjadi kanker serviks yang invasif (invasive cervical cancer $=C I N 3){ }^{(2)}$

Secara genetik, ekspresi onkogen menjadi masalah utama terjadinya kanker serviks. Gen pada sel serviks dapat mengalami mutasi. Sel mutan tersebut tumbuh menjadi klon mutan dan dapat bersifat malignan (ganas). Salah satu onkogen penyebab kanker serviks yaitu gen Faspromoter-670. Gen Fas-promoter-670 terdapat pada kromosom 10 q 24.1, yang mengandung 9 ekson dan 8 intron. ${ }^{(3)}$ Fas (TNFRSF6/Apo1/CD95) merupakan reseptor transmembran tipe 1, termasuk diantaranya yaitu superfamili reseptor faktor nekrosis tumor (tumor necrosis factor $=T N F)^{(4)}$

Hasil penelitian memperlihatkan bahwa polimorfisme nukleotida tunggal atau "single nucleotide polymorphisms (SNPS)" yaitu $-1377 \mathrm{G}>\mathrm{A}$, rs2234767 dan $-670 \mathrm{~A}>\mathrm{G}, \mathrm{rs} 1800682$ terletak di wilayah promoter gen Fas telah diperiksa berkaitan dengan penyakit autoimun ${ }^{(5)}$ dan tumorogenesis. ${ }^{(6)}$ Gagalnya regulasi gen Fas menghasilkan sinyal kematian yang dilaporkan pada beberapa kanker. ${ }^{(7)}$ Ekspresi transkripsi gen Fas diatur oleh sejumlah elemen genetik yang berlokasi di 5'upstream daerah promoter gen. ${ }^{(8)}$ Polimorfisme nukleotida tunggal (single nucleated polimorphism $=S N P$ ) pada 670 di daerah enhancer (A-G) berikatan dengan elemen sinyal aktivasi interferon gamma (gamma interferon activation signal $=G A S)$. Keadaan homozigot alela $\mathrm{G}$ menghasilkan delesi lengkap dari sequen ikatan elemen transkripsi GAS. ${ }^{(9)}$

Penentuan genotip (genotyping) terhadap gen Fas-promoter-670 dapat dilakukan menggunakan teknik restriction fragment lenght polymorphism (RFLP) dengan enzym BstN1. Gen Fas-promoter-670 memiliki 3 genotip yaitu: genotip normal AA (wild-type), varian AG dan GG, sehingga memperlihatkan polimorfisme genetik. Hasil RFLP terhadap gen Fas-promoter-670 menggunakan enzym BstN1 memperlihatkan genotip AA yang terdiri atas 2 pita yaitu 232 dan 98 pasang basa (base pair $=b p$ ), genotip AG terdiri atas 3 pita yaitu 232, 189 dan 98 bp), sedangkan genotip GG terdiri atas 2 pita yaitu 189,98 bp. ${ }^{(10)}$ Frekuensi gen Fas-promoter-670 untuk genotip AA dilaporkan berkisar 25.5-43.6\%, AG 44.2$60.5 \%$ dan GG berkisar $12 \% .^{(11,12)}$

Hasil penelitian sebelumnya memperlihatkan bahwa polimorfisme gen Fas-promoter-670 pada sel punca (stem cells) 
berhubungan dengan kanker serviks di Jepang. ${ }^{(13)}$ Kami menemukan kasus di Indonesia, bahwa ibu berisiko tinggi karena infeksi HPV memperlihatkan bahwa CSEC memiliki biometrik normal. Selain itu, gen Fas-promoter-670 pada sel limfosit bergenotip AA, tetapi pada CSEC bermutasi menjadi AG. ${ }^{(10)}$ Kasus lain memperlihatkan bahwa perempuan berisiko tinggi (karena infeksi HPV) yang bergenotip AG baik pada sel limfosit maupun CSEC juga terinfeksi oleh Candida $s p{ }^{(14)}$

\section{REFERENSI}

1. HPV Information Centre. ICO/IARC Information Centre on HPV and Cancer. 2015. Available from: https://www.hpvcentre.net/index.php

2. Guan P, Howell-Jones R, Li N, Bruni L, de Sanjosé S, Franceschi S, Clifford GM. Human papillomavirus types in 115,789 HPV-positive women: a meta-analysis from cervical infection to cancer. Int J Cancer 2012,131:2349- 2359. Available from: https://www.ncbi.nlm.nih.gov/ pubmed $/ 22323075$

3. Inazawa J, Itoh N, Abe T, Nagata S. Assignment of the human Fas antigen gene (FAS) to 10q24.1. Genomics 1992, 14:821-822. Available from: https://www.ncbi.nlm.nih.gov/pubmed/1385309

4. Nagata S. Apoptosis by death factor. Cell 1997, 88: 355-365. Available from: https://www.ncbi.nlm. nih.gov/pubmed/9039262

5. Molin S, Weiss EH, Ruzicka T, Messer G. The FAS/ cd95 promoter single-nucleotide polymorphism $-670 \mathrm{~A} / \mathrm{G}$ and lupus erythematosus. Clin Exp Dermatol 2012, 37:425-427. Available from: https://onlinelibrary.wiley.com/doi/abs/10.1111/ j.1365-2230.2011.04296.x

6. Farre L, Bittencourt AL, Silva-Santos G, Almeida A, Silva AC, Decanine D, Soares GM, Alcantara Jr LC, Van Dooren S, Galva o-Castro C, Vandamme AM, Van Weyenbergh J. Fas-670 promoter polymorphism is associated to susceptibility, clinical presentation, and survival in adult $\mathrm{T}$ cell leukemia. J Leukocyte Biol 2008, 83:220-223. Available from: https://pdfs.semanticscholar.org/ fa7f/307677c9a3467be5505ca148aa6ad9e17aac. pdf

7. Shimonishi T, Isse K, Shibata F, Aburatani I, Tsuneyama K, Sabit H, Harada K, Miyazaki K, Nakanuma Y. Up-regulation of fas ligand at early stages and down-regulation of Fas at progressed stages of intrahepatic cholangiocarcinoma reflect evasion from immune surveillance. Hepatology 2000, 32: 761-769. Available from: https://aasldpubs.onlinelibrary.wiley.com/doi/ abs/10.1053/jhep.2000.18192

8. Nunobiki O, Ueda M, Toji E, Yamamoto M, Akashi K, Sato N, Izuma S, Torii K, Tanaka I, Okamoto Y, Noda S. Genetic polymorphism of cancer susceptibility genes and HPV infection in cervical carci $\neg$ nogenesis. Patholog Res Int 2011, 3640-69. Available from: https://www.hindawi. com/journals/pri/2011/364069/abs/

9. Kanemitsu S, Ihara K, Saifddin A, Otsuka T, Takeuchi T, Nagayama J, Kuwano M, Hara T. A functional polymorphism in fas (CD95/APO-1) gene promoter associated with systemic lupus erythematosus," Journal of Rheumatology 2002, 29:1183-1188. Available from: https://www.ncbi. nlm.nih.gov/pubmed/12064832

10. Parwanto MLE, Wratsangka R, Guyansyah A, Anggraeni K. Mutation of the Fas-promoter-670 gene, AA to GA in the normal cervix-epithelialcells of high risk Indonesian mother: A case report. Bali Med J 2019, 8 (1):360-364. Available from: https://www.balimedicaljournal.org/index.php/ bmj/article/view/1313/pdf

11. Sun T, Zhou Y, Li H, Han X, Shi Y, Wang L, Miao X, Tan W, Zhao D, Zhang X, Guo Y, Lin D. FASL$844 \mathrm{C}$ polymorphism is associated with increased activation-induced $\mathrm{T}$ cell death and risk of cervical cancer. J Exp Med 2005, 202:967-974. Available from: https:/www.ncbi.nlm.nih.gov/pmc/articles/ PMC2213165/

12. Kordi Tamandani DM, Sobti RC, Shekari M. Association of Fas-670 gene polymorphism with risk of cervical cancer in North Indian population. Clin Exp Obstet Gynecol 2008;35:183-186. Available from: https://www.ncbi.nlm.nih.gov/ pubmed/18754288

13. Ueda M, Terai Y, Kanda K, Kanemura M, Takehara M, Yamaguchi H, Nishiyama K, Yasuda M, and Ueki M. Fas gene promoter -670 polymorphism in gynecological cancer. Int J Gynecol Cancer 2006, 16:179-82. Available from: https://www.ncbi.nlm. nih.gov/pubmed/16515587

14. Parwanto MLE, Wratsangka R, Guyansyah A, Anggraeni K, Digambiro RA, David D, Arkeman H, Edy HJ, Edy YJ, Sisca S, Widyatama HG.. Exploration of cervical-squamous-epithelial-cell (CSEC) biometrics from thinprep Pap smear on GA genotype of Fas-promoter-670 gene in Indonesian women living with highrisk HPV and Candida sp. infection: A case report. SciTech Biomed-Cancer Sciences August 29, 2019. Tokyo-Japan. Available from: https://www.scitcentralconferences.com/ accepteddetails/international-conference-onbiomedical-and-cancer-research/392 